\title{
Technical slip almost forgiven
}

\section{Washington}

A National Institutes of Health (NIH) committee is recommending what hardly amounts to a slap on the wrist for Saul Kit of Baylor College of Medicine for failing to seek prior approval from his Institutional Biosafety Committee before field-testing a new vaccine made by recombinant DNA techniques. The committee also concluded that NIH guidelines need improvement to make clear when a new organism is regulated as a recombinant DNA organism, and what constitutes a deliberate release into the environment.

Early in 1984, an outbreak of pseudorabies, a potentially lethal disease in pigs, occurred on the Maddox farm in Texas. With Stewart McConnell, a veterinarian at Texas A\&M University, Kit devised a plan to vaccinate the pigs on the farm. Kit and McConnell had the approval of the Texas Animal Health Commission. But they never sought NIH approval even though recombinant DNA technology was used in creating the vaccine (Nature 321, 190; 1986).

At issue is whether the vaccine contained recombinant DNA. Recombinant plasmids were used to produce the virus, but the final step yielded a virus made up only of pseudorabies virus DNA with a 148-base-pair deletion. The missing segment codes for thymidine kinase, thought to facilitate entry of the virus into the nervous system of infected animals. The NIH committee also attempted to determine whether testing the vaccine in pigs was a "deliberate release into the environment".

NIH exempts from its guidelines recombinant DNA molecules that "consist entirely of DNA segments from a single nonchromosomal or viral DNA source". But this exemption is nullified if a protocol involves the deliberate release of an organism containing recombinant DNA. Kit maintains that the field test did not constitute an environmental release because the farm was quarantined, the vaccine was apathogenic, and it neither multiplied nor spread from vaccinated pigs.

The NIH committee concluded that ambiguities in the NIH guidelines made it unclear whether Kit's action constituted a violation, but that "an experienced scientist" like Kit should have consulted his Institutionalf Biosafety Committee before proceeding with the field test. The committee recommended that Kit be forced to present plans for all future projects involving animals for a similar vetting procedure, something Kit says he would do in any case. The committee also recommended that NIH clarify their guidelines to remove ambiguities. At the last meeting of the NIH Recombinant DNA Advisory Committee (RAC), new language for the guidelines was proposed specifically to exempt organisms with deletions like

\section{Congress hears of high-tech trade deficit}

\section{Washington}

THE United States is facing its first ever deficit in high technology trade, according to a report* prepared for the Joint Economic Committee of the United States Congress. Although US trade has shown a net deficit since 1982, trade in computers, scientific instruments, aircraft and specialty chemicals has produced surpluses until this year. For the first half of 1986, high technology imports exceeded exports by $\$ 1,300$ million.

The report suggests several reasons for declining trade. An overvalued dollar makes it difficult for US companies to compete in foreign markets. Improvements in the US economy also spurred domestic demand, pulling in imports. But these factors are only part of the explanation. Decisions by other countries to support and protect domestic high technology industries have hurt US competitiveness. Export controls have also put a damper on US ability to exploit overseas markets. Finally the practice of granting "offsets", commercial quid pro quo for the purchase of US military hardware, appears to be having

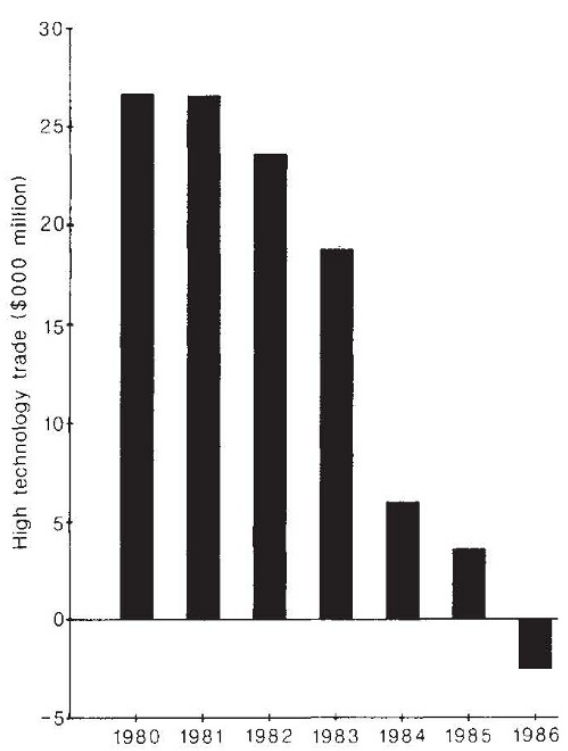

an increasingly important impact on high technology trade. Joseph Palca

*The US trade position in high technology: 1980 1986.
Immunology in India New Delhi

THE National Institute of Immunology in New Delhi was opened by the Prime Minister of India, Mr Rajiv Gandhi, on 6 October. He commended the contribution that immunology can make to solving the country's problems in health care, birth control (see Nature 323,$661 ; 1986$ ) and veterinary practice, and emphasized that applied science in India should not depend solely on basic research in the West. Other speakers, including the Prime Minister's science adviser M.G.K. Menon, stressed that linkage between basic and applied science is both a moral and a practical necessity.

The institute is housed in magnificent new buildings that include palatial animal facilities, a large laboratory block, auditoria and staff housing.

As well as birth-control vaccines, including gamete and trophoblast projects, work at the institute includes leprosy vaccine development, immunodiagnostics and basic work in reproductive immunology using transgenic mice. The director, G.P. Talwar, has been able to tempt back good young Indian scientists from abroad. The institute will help to disseminate the revolutionary impact of molecular biology on immunology. Avrion Mitchison

pseudorabies vaccine.

Kit feels the NIH committee recommendations are a vindication of his position. Kit says he never submitted his plans for the Maddox farm test to the Baylor committee because he believed there was no question of violating NIH guidelines. Joseph Palca

The Biotechnology Science Coordinating Committee, which coordinates federal agencies' policies on recombinant DNA issues, has abandoned research guidelines proposed earlier this year by the US Department of Agriculture (USDA). Many of the comments received by the committee in response to publication of its "coordinated framework" for regulating biotechnology were particularly critical of the USDA guidelines, because they were different from and possibly inconsistent with those of NIH.

The USDA guidelines were published as a contribution to the "coordinated framework" (Federal Register, 26 June, p.23352) to address specifically the needs of agricultural research. But the plan now, according to Dr David Kingsbury, chairman of the coordinating committee, is to develop a unified set of research guidelines to apply to all federally funded research. The new guidelines would be based largely on those of RAC, with expansion of the provisions for environmental releases of genetically altered organisms. Proposals to regulate cell fusion and recombinant RNA would be dropped.

Tim Beardsley 